\title{
Teachers' Views on the Availability of Web 2.0 Tools in Education
}

\author{
https://doi.org/10.3991/ijet.v14i22.11752 \\ Semih Caliskan ${ }^{(\varpi)}$, Zafer Guney \\ Istanbul Aydın University, Istanbul, Turkey \\ semihcaliskan1@aydin.edu.tr \\ Regina G. Sakhieva, \\ Kazan (Volga region) Federal University, Kazan, Russia \\ Dinara G. Vasbieva \\ Financial University under the Government of the Russian Federation, \\ Moscow, Russia \\ Natalia A. Zaitseva \\ Plekhanov Russian University of Economics, Moscow, Russia
}

\begin{abstract}
This research was conducted in 2018 to determine the opinions of prospective teachers about the usability of Web 2.0 tools in education. Quantitative research method was used in the research. The research was conducted in the spring term of 2018-2019. The study group consisted of prospective teachers studying at the faculties of education of the foundation university. 114 prospective teachers participated in the study. The data collection tool called Son the Problems of the Last Year Students of the Faculty of Education and Their Problems in Teaching Practice gelistiril developed by Aylin Demirhan and Meryem Yakut was applied to the teacher candidates. The data were collected by the researchers. The collected data were analysed using the SPSS program. To analyse the data obtained from the data collection tool, frequency, percentage, average, standard deviation, minimum and maximum values, T-test and analysis of variance applied. According to the results of the study, prospective teachers' opinions about the use of Web 2.0 tools are highly positive. It is thought that the students' ability to create content with active participation, support social interaction, and creativity in educational environments, and it is seen in the results of the research that the prospective teachers reported positive opinions. Web 2.0 tools are thought to have a positive effect on learning due to their rich content and may be useful in increasing the prospective teachers' communicative abilities with their common workspaces. Therefore, it is predicted that teachers' use of Web 2.0 tools in their courses will contribute to the development of prospective teachers. In addition, it is thought that the training to be provided by educators who have an important role in guiding prospective teachers and guiding them for a better education will enable prospective teachers to use Web 2.0 tools more frequently and efficiently.
\end{abstract}

Keywords-Web 2.0, technology, education, teacher candidate. 


\section{Introduction}

Adopting these connections in the society with the technology of change and development from past to present, we can constantly fold in this process and we have various abilities to structure and change these changes [1]. Development of technology, education, understanding of the change, to be able to use the current and effective environment and the realities of the good and good agreement [2]. The aim of online social networks, teaching technology, information communication and the transition process in technology networks and teachers' perspectives around different dimensions [3]. Prospective teachers who are in the communication network for learning have started to focus on social media if they plan to work on group work and that they can put their ideas and skills to work [4]. In the days when technology is in this room, teachers are able to respond to this need and learn current communication technologies, and social media circles are transformed into the internet universe and these are the rooms of Web 2.0 [5] [22]. In the study conducted by Yavanoglu, Sagiroglu and Colak [6], online social networks, 'Individuals are defined as tools for social communication in virtual environments created by people by identifying themselves in the social life on the internet and communicating to people with whom they can easily reach the same cultural level by means of internet communication methods and by showing symbolic movements that symbolise various gestures made in normal social life. With the introduction of Web 2.0 technology in 2004, the Education 2.0 period has begun [26]. Web 2.0 technologies social networking sites, which are one of the environments that emerge with its spread and development [7] [23]. A website 2.0 pages focusing on teacher candidates, an easy structure and training areas related to broad product ranges suitable for the elderly and the elderly, the technologies on our website, our options for technologies and the planning of the teacher candidates themselves are planned to be supported [8] [. When all these issues were handled, today's information technology and infrastructure development very rapidly, with the development of the normal web understanding is not used, mostly by providing the effectiveness of preservice teachers said that the structure closer [9] [27]. Along with this change, e-learning systems are also going to new structures with the establishment of teacher candidates, social interaction environment. Looking at the service and applications on the last computer on the web, the menu item states that the content can be focused on (picture, video, article, presentation sharing, etc.), that standard applications and services become operable and that the understanding of different production and the ability to form social networks gains importance [10].

In addition to this information, online social networks, which are among the most beautiful dimensions of their use for educational purposes, do not stop by counting the importance of today's social networks and they have taken their place as indispensable resources of teachers in the educational environment [11]. In today's world, technology-based communication is seen as an integral part of modernity. Society that ideally represents a combination of time and space. Computer change of spaces influences new forms of interpersonal interaction and communication in the information age leads to empirical changes in social life [12]. With the development of Internet technologies, Web 2.0 applications stand out with innovations that will 
completely change the use of the Internet. Web 2.0 enables a person to create content easily and easily on the Internet and facilitates collaboration and social interaction by itself [13]. The usage areas of Web 2.0 technologies are increasing day by day. The main reason for this is that these technologies make the interaction between users, applications and access to information very easy on the internet. Due to these features, it becomes unavoidable to be used in education [14][24]. It can be said that prospective teachers, who are described as the leaders and teachers of the future, should be more equipped, open to learning and to follow the innovations at all times.

\subsection{Related research}

Genc [15], in his study, presents evaluations about the use of Web 2.0 technologies in the field of education, which is among the innovations offered by Web 2.0 technology. Three undergraduate and one graduate course were selected in the sample application used in the study. As a result of the research, it has been concluded that the students have very positive thoughts about the application from their impressions so far and that Facebook is not only a social communication tool but also a learning tool.

Ozmen, Akuzum, Sunkur and Baysal [16] researched the functionality of social networking sites in educational environments in their studies and made necessary infrastructure studies related to the effective use of social networks at all the levels of education, and encouraged teachers to be more effective in educational field use of comprehensive research.

Ekici and Kiyici [17], in their studies, studied the effect of social networks on learning by developing an application on facebook social networking site for students aged 18-24 years. One hundred and two university students participated in the application. The students were divided into two groups as experimental and control groups. In order to reach the findings of the research, the tests were conducted with the achievement test prepared by the researchers. As a result of 4 weeks of practice, it was concluded that the experimental group students were more successful than the control group students who were academically traditionally educated.

Ada, Cicek, Gamze and Kaynakyreens [18], in their studies, aimed to investigate the motivating factors that affect the use of online social networking sites and to determine whether they differ in terms of demographic characteristics. As a result of the research, it was found that motivating factors, such as information search and connectivity differed in terms of gender, and factors, such as information search, problem-solving, content management and connectivity differed in terms of the class of the students. According to other findings, senior students in the department of business administration are more motivated by the use of online social networking sites by factors, such as information search, problem-solving, content management and connectivity than those who are relatively new to the university. Trends wear rates in Science, Technology, Engineering and Mathematics programs are of concern to educators and efforts to reduce this trend continue [19].

Yukselturk and Altiok [20] examined the perceptions of the Scratch tool, which is educational programming, in accordance with the study they prepared. At the end of 
the study, the opinions of prospective teachers were examined and it was seen that the use of Scratch tool was positive. Yukselturk and Altiok [20] stated that it was beneficial in terms of motivation and usefulness as a result of the study [20]. As a result of our research, it is seen that Web 2.0 tools increase school success, and in addition, it is stated in the survey results that it is motivating.

\section{Purpose of the Study}

The overall aim of this study is to determine teachers' opinions about the usability of Web 2.0 tools in education. The following questions were sought for the general purpose identified:

- Are Web 2.0 tools useful in education?

- Is there a meaningful difference in terms of Web 2.0 usability by gender?

- Is there a significant difference between the branches of Web 2.0 usability?

\subsection{Methods}

In this section, determination of teachers' opinions about the use of Web 2.0 tools of university teacher candidates in education and teaching, findings related to the objectives, results and interpretations related to the findings are given.

The study was designed as a quantitative study based on the determination of university teachers' views on the availability of Web 2.0 tools in education and training.

\section{Instruments}

\subsection{Personal information form (demographic data)}

Personal information form: Is gender, department, Web 2.0 useful in education?

Data Collection Tool: The data collection tool developed by Aylin Demirhan and Meryem Yakut called Son the Problems of the Senior Students of the Faculty of Education and Their Problems in School Experience and Teaching Practice kullanilmis was used to collect the data.

The scale, consisting of 31 items and one dimension, was developed as a 5-point Likert type. The scoring of the scale is orum 'I do not agree', 'I do not agree', 'I am undecided', 'ind I do not agree' and orum 'I agree'. In the study, the reliability and validity coefficient of the scale was calculated as $\alpha=0.91$.

\subsection{Participants}

One hundred and fourteen volunteer teachers from the University participated in the study. The research was conducted in 2018 - 2019 Fall Semester. 


\section{Gender}

Table 1. The distribution of teachers by gender

\begin{tabular}{|l|c|c|}
\hline \multicolumn{1}{|c|}{ Gender } & $\boldsymbol{f}$ & \% \\
\hline Male & 35 & 30.7 \\
\hline Female & 79 & 69.3 \\
\hline Total & $\mathbf{1 1 4}$ & $\mathbf{1 0 0 . 0}$ \\
\hline
\end{tabular}

As can be seen in Table 1, 30.7\% (35 people) of the teachers were male and $69.3 \%$ (79 people) were female teacher candidates. In the gender section, the findings reflect the actual gender distribution.

Branch: Table 2 shows the distribution of teachers by the branch.

Table 2. Branch distribution of teachers participating in the research

\begin{tabular}{|l|c|c|}
\hline \multicolumn{1}{|c|}{ Branch } & $\boldsymbol{f}$ & \% \\
\hline Computer Education and Instructional Technology & 25 & 21.93 \\
\hline Science and Technology & 10 & 8.77 \\
\hline English Teacher & 14 & 12.29 \\
\hline Library & 10 & 8.77 \\
\hline Math Teaching & 10 & 8.77 \\
\hline Psychological and Guidance Counselling & 10 & 8.77 \\
\hline Classroom Teaching & 15 & 13.16 \\
\hline Turkish Teacher & 10 & 8.77 \\
\hline Manager & 10 & 8.77 \\
\hline Total & $\mathbf{1 1 4}$ & $\mathbf{1 0 0 . 0}$ \\
\hline
\end{tabular}

As can be seen in Table 2, the distribution of the working group teachers by departments is given. Among the most prominent findings of the study group, $21.93 \%$ (25 people) consisted of Computer and Instructional Technology Teaching, $13.16 \%$ (15 people) Classroom Teachers and 12.29\% (14 people) English teachers. In the branch section, the findings reflect the actual section distribution.

Web 2.0 tools in education is useful?

Table 3 shows whether the Web 2.0 tools of the teachers participating in the research are useful in education.

Table 3. Distribution of Web 2.0 tools useful in education by teachers

\begin{tabular}{|l|c|c|}
\hline \multicolumn{1}{|c|}{ Web 2.0 tools in education is useful } & $\boldsymbol{f}$ & \% \\
\hline Yes & 110 & 96.50 \\
\hline No & 4 & 3.5 \\
\hline Total & $\mathbf{1 1 4}$ & $\mathbf{1 0 0 . 0}$ \\
\hline
\end{tabular}

As Table 3 shows, are the Web 2.0 tools of the working group teachers useful in education? $96.50 \%$ of the distributions on the question (110 people) Yes, 3.5\% (10 people) It is seen that no answers. When Table 3 is examined, it can be said that 110 teachers answered yes and accordingly Web 2.0 tools are useful in education. 


\section{$4 \quad$ Results and Discussion}

In this section, the opinions of university teachers about the usability of Web 2.0 tools in education and teaching and the results and interpretations related to the findings are given.

Table 4. Prospective Teachers' Views on the Usability of Web 2.0 Tools in Education

\begin{tabular}{|c|c|c|}
\hline Substances & Mean & Std. deviation \\
\hline 1. I believe that Web 2.0 tools play an important role in education. & 4.68 & 0.535 \\
\hline $\begin{array}{l}\text { 2. I believe that the teacher who uses Web } 2.0 \text { tools will bring vitality and } \\
\text { movement to the classroom through the activities and programs that she } \\
\text { brings to the classroom. }\end{array}$ & 4.62 & 0.553 \\
\hline 3. Students have an important role in feedback. & 4.28 & 0.780 \\
\hline $\begin{array}{l}\text { 4. I believe that the more current and functional content of the courses } \\
\text { will increase. }\end{array}$ & 4.43 & 0.689 \\
\hline 5. I believe that students using Web 2.0 tools will remain active. & 4.50 & 0.653 \\
\hline 6. I think it is enhancing school success and motivation. & 4.49 & 0.680 \\
\hline $\begin{array}{l}\text { 7. I believe it will be useful for effective course design and preparation of } \\
\text { presentations. }\end{array}$ & 4.60 & 0.672 \\
\hline $\begin{array}{l}\text { 8. It provides the collaborative work of the students with common } \\
\text { working areas. }\end{array}$ & 4.41 & 0.805 \\
\hline $\begin{array}{l}\text { 9. I think that social interaction (student-teacher or teacher-student) is } \\
\text { active. }\end{array}$ & 4.37 & 0.742 \\
\hline 10. I think Web 2.0 tools support creativity. & 4.35 & 0.839 \\
\hline $\begin{array}{l}\text { 11. I think that the rich content of Web } 2.0 \text { tools will enable students to } \\
\text { participate actively. }\end{array}$ & 4.52 & 0.705 \\
\hline $\begin{array}{l}\text { 12. It enables students to become technology literate, active and } \\
\text { participatory individuals in their future lives. }\end{array}$ & 4.38 & 0.801 \\
\hline $\begin{array}{l}\text { 13. As it is product-oriented with Web } 2.0 \text { tools, it is seen as a concrete } \\
\text { example of the effort shown. }\end{array}$ & 4.43 & 0.773 \\
\hline 14. It enables the student to work outside the classroom. & 4.42 & 0.738 \\
\hline $\begin{array}{l}\text { 15. I think Web } 2.0 \text { tools will be useful for students with different } \\
\text { learning styles. }\end{array}$ & 4.53 & 0.680 \\
\hline $\begin{array}{l}\text { 16. Students participate in the educational environment with more } \\
\text { sensory organs, which allows them to acquire more memorable } \\
\text { information. }\end{array}$ & 4.55 & 0.729 \\
\hline 17. I think that students will develop spatially, logically and socially. & 4.52 & 0.717 \\
\hline $\begin{array}{l}\text { 18. It gives students the right to go beyond textbooks, create content, and } \\
\text { manipulate content, which helps students develop their self-confidence. }\end{array}$ & 4.52 & 0.820 \\
\hline $\begin{array}{l}\text { 19. The information generated by the Web } 2.0 \text { tools reaches a wide } \\
\text { audience, which will enable the student to work product-oriented. }\end{array}$ & 4.54 & 0.740 \\
\hline
\end{tabular}

When Table 4 is examined, when teachers' opinions about the usability of Web 2.0 tools in education are examined, belirgin 'I believe that Web 2.0 tools have an important role in education' $(M=4.68, \mathrm{SD}=0.535)$, and also, 'The activity that the teacher using Web 2.0 tools brings to the classroom' $(M=4.62, \mathrm{SD}=0.672)$. When Table 4 is examined, it is seen that the statements given to the other options are answered at the level of 'agree'. 


\subsection{Results of university teachers' use of Web 2.0 tools for gender criteria in education and training}

In Table 5, data on independent samples $t$-test results are given to determine whether there is a significant difference between the results of University teachers' Web 2.0 Tools for Education and Teaching.

Table 5. The usability of Web 2.0 cross-currencies for gender criteria of university teachers in education

\begin{tabular}{|c|c|c|c|c|c|c|c|}
\hline \multirow{3}{*}{$\begin{array}{l}\text { The use of } \\
\text { Web } 2.0 \text { tools } \\
\text { in education } \\
\text { and training }\end{array}$} & Group & $N$ & $\bar{X}$ & SD & Df & $t$ & $p$ \\
\hline & Male & 35 & 1.74 & \multirow{2}{*}{53.20} & \multirow{2}{*}{114} & \multirow{2}{*}{3.046} & \multirow{2}{*}{0.121} \\
\hline & Female & 79 & 1.57 & & & & \\
\hline
\end{tabular}

As can be seen in Table 5, among the results of the comparison of the university teachers' Web 2.0 tools in terms of gender criterion in education and training, the availability of male teachers' Web 2.0 tools in education and training was determined as $(\bar{X}=1.74, \mathrm{SD}=53.20$ ), while the female teachers' Web 2.0 Tools were found to be in the same way. Arithmetic mean and standard deviation scores $(\bar{X}=1.57, \mathrm{SD}=$ 53.20) of the Availability of Teaching were determined. From this finding, it was seen that there was no significant difference between the gender of university teachers $(t=$ $3.046, p>0.001)$.

\subsection{One-way analysis of variance (ANOVA) results of university teachers' branch criteria for Web 2.0 tools}

Table 6 presents the results of the One-Way ANOVA results for the comparison of the use of Web 2.0 tools for the branch teachers' criterion.

Table 6. Comparison of university 2.0 teachers' Web 2.0 tools for education criteria one-way ANOVA results

\begin{tabular}{|c|c|c|c|c|c|}
\hline Department & $N$ & Sira Ortalamasi & SD & $X^{2}$ & $p$ \\
\hline Classroom Teaching & 15 & 4.30 & \multirow{4}{*}{9} & \multirow{4}{*}{0.770} & \multirow{4}{*}{.000} \\
\hline English Teaching & 14 & 4.74 & & & \\
\hline $\begin{array}{l}\text { Computer Education and Instructional } \\
\text { Technology }\end{array}$ & 25 & 4.80 & & & \\
\hline Psychological and Guidance Counselling & 10 & 4.48 & & & \\
\hline Library & 10 & 4.38 & & & \\
\hline Science and Technology & 10 & 4.05 & & & \\
\hline English Teacher & 10 & 4.29 & & & \\
\hline Math Teaching & 10 & 4.44 & & & \\
\hline Manager & 10 & 4.48 & & & \\
\hline Total & 114 & & & & \\
\hline
\end{tabular}

As can be seen in Table 6, a significant difference was found in the comparison results of the use of Web 2.0 tools for the branch criterion of university teachers in 
education and training $\left[\chi^{2}(9)=0.770 ; p=.000 ; p<0.05\right]$. When the comparison results regarding the usability of Web 2.0 tools for the branch criterion of university teachers were evaluated, the highest value among the branches was CEIT and the lowest value was Science and Technology. According to these findings, it can be said that there is a significant difference between the branches in terms of the availability of Web 2.0 tools for the branch criteria of university teachers in education and training.

\section{Conclusion and Discussion}

According to the results of the study, are the Web 2.0 tools of the working group teachers useful in education? $96.50 \%$ of the distributions on the question (110 people) Yes, 3.5\% (10 people) No answers, in this context, teachers find Web 2.0 tools useful in education, Web 2.0 tools combined with education, both education and It can be said to be useful to teacher candidates. In addition, Genc [15] presents evaluations on the use of Web 2.0 technologies in the field of education, which is among the innovations offered by Web 2.0 technology. Social Media is a group of Internet-based applications that are based on the ideological and technological basis of Web 2.0 and allow the creation and modification of the Internet [25] User Generated Content Three undergraduate and one graduate courses were selected in the sample application used in the study. As a result of the research, it has been concluded that the students have very positive thoughts about the application from their impressions so far and that Facebook is not only a social communication tool but also a learning tool. In this context, it can be said that pre-service teachers found the technology tools useful in education, they enjoyed using them in education, and finally, the pre-service teachers had positive thoughts.

When the other results of the study are taken into consideration, the availability of Web 2.0 tools for education and training $(\bar{X}=1.74, \mathrm{SD}=53.20)$ of the male teachers was determined as the comparison of the availability of Web 2.0 tools for education and training to the gender criteria of university teachers. Arithmetic mean and standard deviation scores of the availability cases $(\bar{X}=1.57, \mathrm{SD}=53.20)$ were determined. It was concluded that there was no significant difference between the gender of university teachers $(t=3.046, p>0.001)$. In addition, when the literature is examined, it is stated that there is no significant gender-related difference in teachers' attitudes in some studies [21]. In this context, it can be said that teachers do not differ according to gender, whether male or female teachers welcome the use of Web 2.0 technology in education, and when the literature is evaluated, it is concluded that there is no difference between the genders in similar studies.

Finally, when we look at the results of the study, it is seen that there is a significant difference between the results of the comparison of the Web 2.0 tools for the use of the Web 2.0 tools for the branch criteria of university teachers $\left[\chi^{2}(9)=0.770 ; p=\right.$ $.000 ; p<0.05]$. When the comparison results regarding the usability of Web 2.0 tools for the university teachers' branch criterion are examined, the highest value among the branches is determined as CEIT while the lowest value is Science and Technology. 
According to these findings, it is seen that the usability of Web 2.0 tools in terms of the Branch Criterion of University Teachers in education-teaching is a significant difference between the departments. In this context, if we take the findings into consideration, it shows the importance of teachers' use of Web 2.0 tools in education. $95 \%$ of teachers stated that these tools should be used in education.

According to the results of the study, teachers' opinions about the use of Web 2.0 tools are highly positive. It is thought that the students' ability to create content with active participation, support social interaction and creativity in educational environments, and it is seen in the results of the research that the teachers expressed a positive opinion. Web 2.0 tools are thought to have a positive effect on learning due to their rich content and may be useful in increasing the prospective teachers' communicative abilities with their common workspaces. Therefore, it is predicted that preservice teachers' use of Web 2.0 tools in their courses will contribute to the development of prospective teachers. If we consider the results of the study, they can make some suggestions to the prospective teachers as follows

- Innovative initiatives should be taken to meet the training needs and aspirations of prospective teachers about Web 2.0 technologies and applications, and if a planned training program is implemented, it should be provided with in-service training.

- Due to the development of technology and the need to update Web 2.0 tools, it is recommended to update the studies in this context every year to other researchers who will contribute to the literature.

- Last, it is thought that the training to be provided by educators who have an important role in guiding prospective teachers and guiding them for a better education will enable prospective teachers to use Web 2.0 tools more frequently and efficiently.

\section{Acknowledgement}

- The work is performed according to the Russian Government Program of Competitive Growth of Kazan Federal University.

- The work is performed according to the Program of Development of Financial University under the Government of the Russian Federation for 2020.

\section{$7 \quad$ References}

[1] Korucu, A., Korucu, A. T., Cakir, H. (2015). Dinamik Web Teknolojileri Ile Gelistirilen Isbirlikli Ogrenme Ortamini Kullanan Ogretmen Adaylarinın Gorusleri. Adiyaman Universitesi Sosyal Bilimler Enstitusu Dergisi, 2015(19): 221-254. Available from: https://doi.org/10.14520/adyusbd.61147

[2] Seferoglu, S. S. (2004). Ogretmen yeterlilikleri ve mesleki gelisim. Bilim ve Aklin Aydinliginda Egitim, 58: 40-45. Available from:http://yunus.hacettepe. edu.tr/ \%20sadi/yayin/Seferoglu Ogretmen Yeterlikleri BAAE 2004-58.pdf 
[3] Solmaz, B., Tekin, G., Herzem, Z., Demir, M. (2013). Internet ve sosyal medya kullanımı uzerine bir uygulama. Selcuk Universitesi Iletisim Fakultesi Akademik Dergisi, 7(4): 2332. Available from: http://josc.selcuk.edu.tr/article/view/1075000023

[4] Salih, U. S. L. U., Hamarat, E. (2016). Sosyal Bilgiler Ogretmen Adaylarinin Sosyal Aglari Kullanim Amaclarinin Belirlenmesi. e-Kafkas Egitim Arastirmalari Dergisi, 3(1): 6-35. Available from: http://dergipark.org.tr/kafkasegt/issue/19198/204121

[5] Lee, R. B., Baring, R., Maria, M. S., Reysen, S. (2017). Attitude towards technology, social media usage and grade-point average as predictors of global citizenship identification in Filipino University Students. International Journal of Psychology, 52(3): 213-219. Available from: https://doi.org/10.1002/ijop.12200

[6] Yavanoglu, U., Seref Sagıroglu, S., Ilhami Colak, I. (2012). Sosyal aglarda bilgi guvenligi tehditleri ve alinmasi gereken onlemler. Politeknik Dergisi, 15(1): 1. Available from: https://dergipark.org.tr/download/article-file/385621

[7] Sen, M. (2016). Teknolojik ogretim araclari ve ozellikleri. Pegem Atif Indeksi, 83-109. Available from: https://doi.org/10.14527/9786053184539.06

[8] Elmas, R., Geban, O. (2012). Web 2.0 tools for 21st century teachers. International Online Journal of Educational Sciences, 4(1): 243-254. Available from: https://www.researchgate.net/publication/264856610_Web_20_Tools_for_21st_Century_T $\underline{\text { eachers }}$

[9] Bayazit, A., Bayram, S., Cumaoglu, G. (2019). Investigating the relationship between task complexity, cognitive ability and disorientation in hypertext navigation. World Journal on Educational Technology: Current Issues, 10(4): 286-298. Available from: https://doi.org/10.18844/wjet.v10i4.4088

[10] Abuhlfaia, K., de Quincey, E. (2018). The Usability of E-learning Platforms in Higher Education: A Systematic Mapping Study. Proceedings of the 32nd International BCS Human Computer Interaction Conference (p. 7). BCS Learning \& Development Ltd. Available from: https://www.scienceopen.com/document?vid=c13818aa-430c-4f13-ac0963ae438433a1

[11] Kaya, Z., Yilayaz, O. (2013). Ogretmen egitimine teknoloji entegrasyonu modelleri ve teknolojik pedagojik alan bilgisi. Bati Anadolu Egitim Bilimleri Dergisi, 4(8): 57-83. Available from: https://dergipark.org.tr/download/article-file/39520

[12] Eraslan, L., Kukuoglu, A. (2019). Social relations in virtual world and social media aggression. World Journal on Educational Technology: Current Issues, 11(2): 01-11. https://doi.org/10.18844/wjet.v11i2.4145

[13] Atici, B., Yıldırım, S. (2010). Web 2.0 araclarinin e-ogrenmeye etkisi. Akademik Bilisim 2010'da sunulan bildiri, Mugla Universitesi, Mugla, Turkiye. Available from: https://ab.org.tr/ab10/kitap/atici_yildirim_AB10.pdf

[14] Deperlioglu, O., Kose, U. (2010). Web 2.0 teknolojilerinin egitim uzerindeki etkileri ve ornek bir ogrenme yasantisi. Akademik Bilisim, 10-12. Available from: https://www.researchgate.net/profile/Utku_Koese/publication/280230890_Web_20 teknol ojilerinin egitim uzerindeki etkileri ve ornek bir ogrenme yasantisi/links/578cd73e08a e7a588ef3cfa8.pdf

[15] Genc, H. (2010). Internetteki etkilesim merkezi sosyal aglar ve e-is 2.0 uygulamalari. Akademik Bilisim, 481-487. Available from:https://ab.org.tr/ab10/kitap/genc eis AB10.pdf

[16] Ozmen, F., Akuzum, C., Sunkur, M., Baysal, N. (2011, May). Sosyal ag sitelerinin egitsel ortamlardaki islevselligi. 6th International Advanced Technologies Symposium (IATS'11), pp 16-18. Available from: https://pdfs.semanticscholar.org/baad/ff92851eec00eb4 $\underline{\text { ef75b80a15f67c3df80a6.pdf }}$ 
[17] Ekici, M., Kiyici, M. (2012). Sosyal aglarin egitim baglaminda kullanimi. Available from: https://doi.org/10.12780/UUSBD120

[18] Ada, S., Cicek, B., Kaynakyesil, G. (2013). Cevrimici sosyal ag sitesi kullanımını etkileyen motive edici faktorler uzerine bir arastirma. Academic Informatics Conference, Antalya. Available from: https://ab.org.tr/ab13/bildiri/206.pdf

[19] Said, M. M., Aravind, V., James, D., Umachandran, K. (2019). Dissecting assessment: A paradigm shift towards technology-enhanced assessments. World Journal on Educational Technology: Current Issues, 11(2): 24-32. https://doi.org/10.18844/wjet.v11i2.4148

[20] Yukselturk, E., Altiok, S. (2016). Bilisim teknolojileri ogretmen adaylarinin programlama ogretiminde Scratch aracinin kullanimina iliskin algilari. Mersin Universitesi Egitim Fakultesi Dergisi, 12(1). https://doi.org/10.17860/efd.94270

[21] Kutluca, T., Ekici, G. (2010). Ogretmen adaylarının bilgisayar destekli egitime iliskin tutum ve oz-yeterlik algilarinin incelenmesi. Hacettepe Universitesi Egitim Fakultesi Dergisi, 38: 17-188. Available from:http://www.efdergi.hacettepe.edu.tr/yonetim/icerik/ makaleler/426-published.pdf

[22] Danilov, A., Zaripova, R., \& Anyameluhor, N. (2018). Using wiki in the design of bilingual online course. Cypriot Journal of Educational Sciences, 13(4), 480-488. https://doi.org/10.18844/cjes.v13i4.3893

[23] Soyluçiçek, S. (2018). Looking through the sphere; Illustration in virtual reality. New Trends and Issues Proceedings on Humanities and Social Sciences, 5(6), 53-59. https://doi.org/10.18844/prosoc.v5i6.3695

[24] Kurniawan, D. A., Lumbantoruan, A., \& Samosir, S. C. (2019). Mobile Learning in Higher Education for The Industrial Revolution 4.0: Perception and Response of Physics Practicum. International Journal of Interactive Mobile Technologies, 13(9). https://doi.org/10.3991/ijim.v13i09.10948

[25] Rautela, S., \& Sharma, A. (2019). Spirituality and Social Media: Connecting the Dots. International Journal of Interactive Mobile Technologies, 13(9). https://doi.org/10. 3991/ijim.v13i09.8863

[26] Keser, H., \& Semerci, A. (2019). Technology trends, Education 4.0 and beyond. Contemporary Educational Researches Journal, 9(3), 39-49.https://doi.org/10. 18844/cerj.v9i3.4269

[27] Uzunboylu, P. D. H., \& GündogduE. (2018). A Content Analysis Study on Pre-School Education and Instructional Technologies. International Journal of Innovative Research in Education, 5(4), 119-128. https://doi.org/10.18844/ijire.v5i4.3974

\section{Authors}

Semih Caliskan is lecturer. of İstanbul Aydın University, Department of Distance Learning Center of İstanbul Aydin Üniversity. His research technology, computer and special learning. He has more than 10 published papers in web of science and scopus. E-mail id: semihcaliskan1@aydin.edu.tr

Zafer Guney is Assist Professor of the Department of Education Faculty in İstanbul Aydin University. His research technology, computer and mobile technology. He has more than 10 published papers in web of science and scopus. E-mail id: zaferguney@aydin.edu.tr

Regina G. Sakhieva is $\mathrm{PhD}$ in Education, Associate Professor of the Department of Pedagogy of Higher Education of the Institute of Psychology and Education at 
Kazan (Volga region) Federal University (18 Kremlyovskaya Street, 420000, Kazan, Russia). Her research interests are related to the methodology of teacher education, educational programs design, content selection. She has more than 100 published papers in Russian and International reputable journals. E-mail id: $\underline{\text { saxievarg@mail.ru }}$

Dinara G. Vasbieva is $\mathrm{PhD}$ in Economics, Associate Professor of the Department of Foreign Languages at Financial University under the Government of the Russian Federation (49 Leningradsky prospect, 125993, Moscow, Russia). Her research interests for the last decade have been largely concerned with the problems of methodology in education and linguistics, e-learning environment and energy saving economics. She has more than 70 articles published in different international journals. E-mail id: dinara-va@list.ru

Natalia A. Zaitseva is a Doctor of Economics, Professor of the Department of Hospitality, Tourism and Sports Industry at Plekhanov Russian University of Economics (36 Stremyannyi Pereulok, 115093, Moscow, Russia). Her main scientific and professional interests are connected with professional standards and assessment of personnel qualifications in the tourism and hospitality industry, she actively studies strategic management of tourism development in the regions, the strategy for building human capital at the macro and micro levels, effective management and selfmanagement. She is a member of 3 dissertation councils of some Russian universities for the defense of doctoral and PhD theses. E-mail id: zaitseva-itig@mail.ru

Article submitted 2019-09-24. Resubmitted 2019-10-20. Final acceptance 2019-10-21. Final version published as submitted by the authors. 